\title{
Terrestrial Carbon Pools: Preliminary Data from the Corn Belt and Great Plains Regions ${ }^{1}$
}

\author{
Edward T. Elliott, Ingrid C. \\ Burke, Christopher A. Monz, \\ and Serita D. Frey \\ Colorado State University \\ Fort Collins, Colorado \\ Keith H. Paustian and Harold \\ P. Collins \\ Kellogg Biological Station \\ Michigan State University \\ Hickory Corners, Michigan \\ Eldor A. Paul \\ Michigan State University \\ East Lansing, Michigan \\ C. Vernon Cole \\ USDA-ARS \\ Colorado State University \\ Fort Collins, Colorado \\ Robert L. Blevins and \\ Wilbur W. Frye \\ University of Kentucky \\ Lexington, Kentucky
}

Drew J. Lyon

University of Nebraska

Scotts Bluff, Nebraska

Ardell D. Halvorson

USDA-ARS

Akron, Colorado

David R. Huggins

Southwest Experiment Station

Lamberton, Minnesota

Ronald F. Turco

Purdue University

West Lafayette, Indiana

Michael V. Hickman

USDA-ARS

Purdue University

West Lafayette, Indiana

Soil organic matter is recognized as an important component of soil quality (Granatstein \& Bezdicek, 1992; Arshad \& Coen, 1992). In mineral soils, many properties associated with soil quality, including nutrient mineralization, aggregate stability, trafficability, and favorable water relations are related to the soil organic matter content. Past considerations of soil organic matter and how it is affected by management practices have largely reflected the

\footnotetext{
${ }^{1}$ This research is supported by the USEPA (Project AERL-9101) and the USDA-ARS. 
importance of organic matter to soil fertility and crop production. More recently, interest in soil organic matter and its relationship to agricultural management has developed with respect to its role in the worldwide $\mathrm{C}$ budget and worldwide climate change, another important quality of soil.

The conversion of native ecosystems to agriculture usually results in a loss of soil organic matter. Such losses are well-documented for the Great Plains and Corn Belt regions of North America (Jenny, 1941; Haas \& Evans, 1957; Campbell, 1978). Worldwide, soil C losses associated with agricultural expansion and intensification since the mid-1800s have contributed significantly to increased atmospheric $\mathrm{CO}_{2}$ (Post et al., 1990; Wilson, 1978). There is growing interest in reversing this trend through changes in agricultural practices to make soil a net sink for C.

The research described in this chapter was initiated to assess the potential for $\mathrm{C}$ sequestration in agricultural soils of the Great Plains and Corn Belt regions (Barnwell et al., 1992). However, understanding the factors governing changes in soil organic matter pool sizes (e.g., climatic, edaphic, and management factors) is also crucial for assessment of other essential aspects of soil quality and its response to management.

Data from long-term field studies has provided much information about changes in soil $C$ under various management regimes, but our knowledge base is fragmented. Most of what we know concerning soil organic matter (SOM) dynamics has been obtained by studying SOM losses. We understand less about controls on SOM accumulation and how they vary across soil types, climatic regions, and management regimes. Such information is crucial for estimating the potential for $\mathrm{C}$ sequestration in agricultural soils of the Great Plains and Corn Belt regions.

Our approach to assessing potential $\mathrm{C}$ sequestration in agroecosystems is based on relating key driving variables to ecosystem processes and properties. Driving variable control can explain soil properties and their geographic distribution (Jenny, 1941; Elliott et al., 1993). This framework acknowledges that soils are one of many interrelated ecosysem components.

Understanding soil $\mathrm{C}$ dynamics and assessing potential $\mathrm{C}$ sequestration in soil requires investigation of the functioning of the whole ecosystem with its inherent interactions and feedbacks. Relationships between soil $\mathrm{C}$ management, climate, and soil type cannot be adequately resolved using empirical statistical approaches because of these interactions and feedbacks. The best way to accomplish this integration is through the use of simulation models (e.g., Parton et al., 1987; Paustian et al., 1992; Jenkinson et al., 1987).

Agroecosystem models must be validated over a wide range of management practices, climates, soils, and time scales to be generally applicable. Fortunately, there are appropriate data available from long-term field experiments (Elliott \& Cole, 1989). These experiments are located on research sites of the USDA-ARS, state experiment stations, Agriculture Canada, and other countries. They constitute the largest and longest-term set of ecological experiments currently available. However, this information is not organized into comprehensive data bases and essential information has not been collected at every site. 
The objective of this research is to develop reliable data sets to assess the potential for $\mathrm{C}$ sequestration in agroecosystems of the Great Plains and Corn Belt. To supplement existing information, we are sampling a number of long-term field experiments to obtain a uniform characterization of soil organic matter and organic matter inputs relating to specific active fraction pools (particulate organic matter, $\mathrm{CHCl}_{3}$, labile $\mathrm{C}$, and mineralized $\mathrm{C}$ ) useful for parameterizing and validating SOM models. This chapter represents the spring sampling of six sites within the current network of 41 sites (Fig. 12-1), three from the Corn Belt and three from the Great Plains.

\section{MATERIALS AND METHODS}

\section{Sampling}

All sites (Table 12-1) were sampled in the spring of 1992 prior to cultural operations. Six 5.6-cm cores were collected and composited from each field replicate using a truck-mounted hydraulic soil exploration probe. Each soil core was divided into four depth increments; 0 to 20,20 to 25,25 to 50 , and 50 to $100 \mathrm{~cm}$. The 0 to 20 and 20 to $25 \mathrm{~cm}$ increments allow us to adjust for potential differences in bulk density in different management practices so that we can express our data based on an equivalent soil weight as well as an equivalent soil depth. For no-till and grassland treatments, six additional 5.6 by $2.5 \mathrm{~cm}$ cores were collected and composited from the surface $2.5 \mathrm{~cm}$ of mineral soil. In addition, surface residues from three $0.25 \mathrm{~m}^{2}$ areas were collected at random within each no-till field replicate.

Immediately after collection, soil samples were put on ice for transport to the laboratory. Surface $(0-20 \mathrm{~cm})$ samples used in biological analyses were stored at $4{ }^{\circ} \mathrm{C}$ for no more than $24 \mathrm{~h}$ and sieved moist to pass a $2-\mathrm{mm}$ screen prior to incubation. Remaining samples were air-dried, crushed, then sieved after removal of large plant fragments. Crop residues, roots, and rock fragments within each sample were rmeoved, dried, and weighed. All data reported in this chapter are reported to a 20 -cm depth.

\section{Soil Analysis}

Total C was determined by dry combustion of duplicate subsamples from each depth for each treatment replicate on a Carlo Erba CHN analyzer Model 1104 (Carlo Erba Instruments, Milano, Italy). Soil texture and particulate organic matter (POM-C) were determined by a modified version of the Cambardella and Elliott (1992) method. Briefly, POM was isolated by dispersing $30 \mathrm{~g}$ of soil in $5 \%$ sodium hexametaphosphate and passing the dispersed sample through a 53- $\mu \mathrm{m}$ sieve, which retains the POM fraction plus sand and allows the passage of mineral-associated SOM. The sand plus POM fraction was dried $\left(50^{\circ} \mathrm{C}\right)$, finely ground, and subsampled for total organic $\mathrm{C}$. The soil slurry passing through the sieve was transferred to a 1-L sedimentation cylinder, and the silt and clay content determined using the hydrometer 


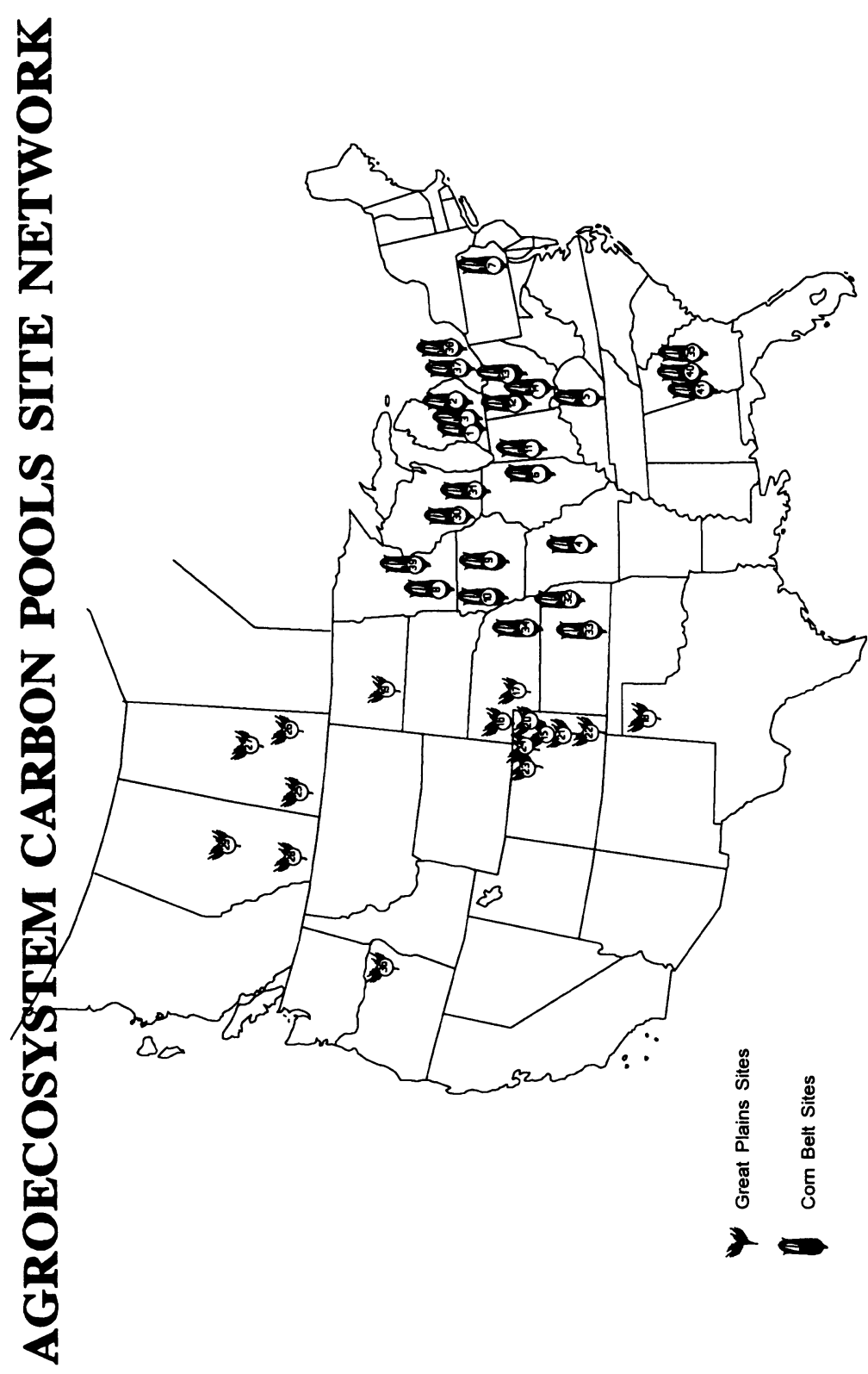

$\Xi$

ํㅡㄹ.

氧

닌

营 ह

于

悫

인

站

范

苟字

可

कo

。

次

:

0

วิธี็.

उृ

表

改

원

氙若.

卷起

क क

苍造

\%

․․묻

㻤

号焉

음으

สำ

需 $\infty$

气

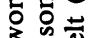

这

至

范

.

모

范.

它它

ซี

능능 호

品

U

๕نㅇ

F岂

충

की 


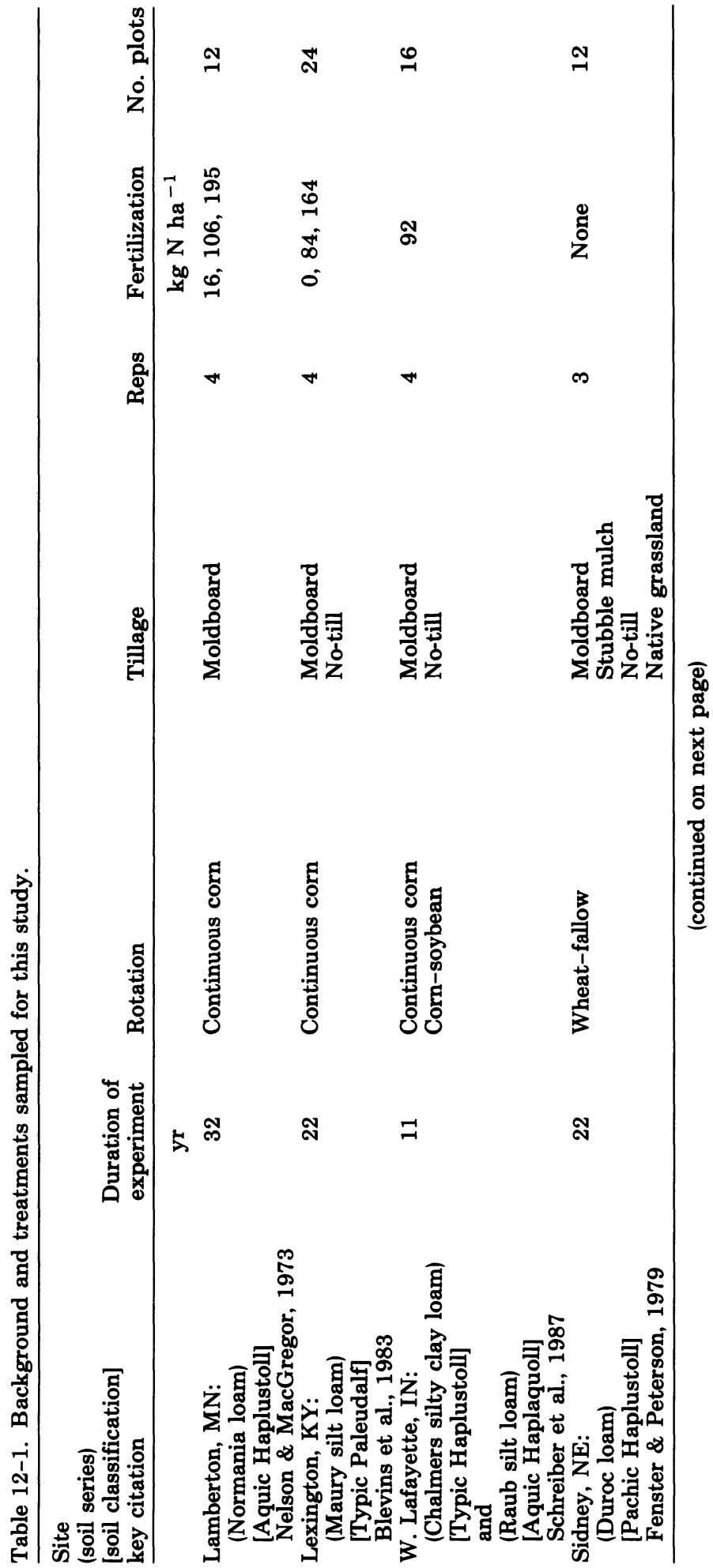




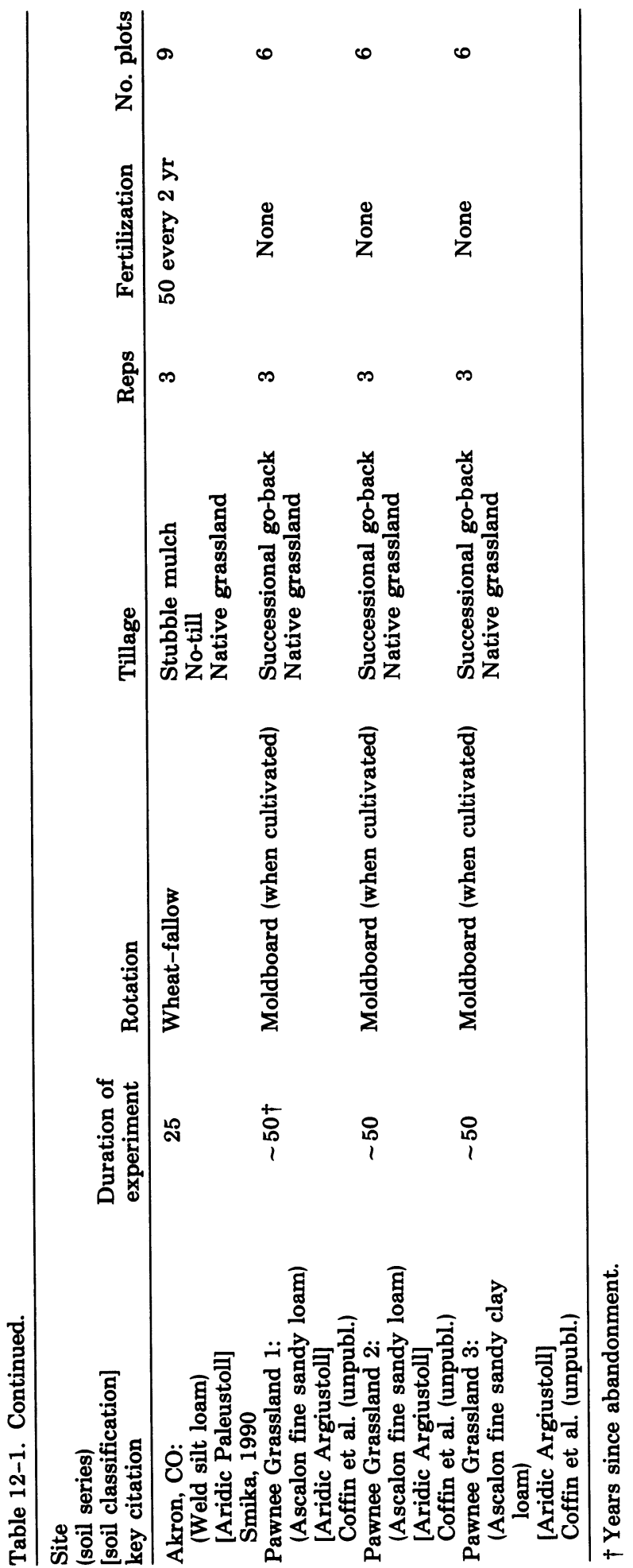


method. Bulk density was determined from the number of cores collected and volume of the core that each depth increment represented.

Moist soil subsamples from the 0 to $20-\mathrm{cm}$ depth increment were used to determine mineralized $\mathrm{C}$ and $\mathrm{CHCl}_{3}$ labile $\mathrm{C}$. Field capacity water content for each soil sample was determined by a volumetric soil water method. These water contents were used for subsequent soil incubations. Briefly, dried and sieved soils were packed into $50 \mathrm{~cm}^{3}$ tubes. Enough water was added to wet approximately half of the soil in the tube. The soil in the columns was allowed to equilibrate with the water for $18 \mathrm{~h}$, after which the wet soil was removed and moisture content determined. Even though matric potential measurements were available for most soils sampled, we decided to use the above method to assure uniformity of moisture content across the many soil types.

Mineralized soil $\mathrm{C}$ was determined by incubating duplicate $25 \mathrm{~g}$ soil samples in $160-\mathrm{mL}$ bottles at $25^{\circ} \mathrm{C}$ for $91 \mathrm{~d}$. Headspace $\mathrm{CO}_{2}$ was measured using a Beckman Model 865 infrared gas analyzer (Beckman Instruments, Fullerton, CA) at 2, 4, 7, 10, and then $14 \mathrm{~d}$ intervals to $91 \mathrm{~d}$. Following analysis, each sample was returned to ambient $\mathrm{CO}_{2}$ by de-gassing with compressed air.

Chloroform labile $\mathrm{C}$ (i.e., released microbial biomass $\mathrm{C}$ ) was estimated by the chloroform fumigation-extraction method as described by Vance et al. (1987) and Tate et al. (1988), except that $12 \mathrm{~g}$ of moist soil was used rather than the usual $25 \mathrm{~g}$ dry weight equivalent. Prior to fumigation, soil samples were preincubated at field capacity for $7 \mathrm{~d}\left(25^{\circ} \mathrm{C}\right)$ to normalize vagarities of weather relative to sampling data across sites. Soluble organic $\mathrm{C}$ was extracted from duplicate fumigated and control samples using $0.5 \mathrm{M} \mathrm{K}_{2} \mathrm{SO}_{4}$ and oxidized in a sulfuric-phosphoric acid dichromate mixture (Snyder \& Trofymow, 1984). Carbon dioxide liberated during digestion was trapped in $0.1 \mathrm{M} \mathrm{NaOH}$ and titrated with $\mathrm{HCl}$ (Anderson, 1982).

\section{RESULTS}

\section{Corn Belt Sites (Table 12-2)}

\section{Lamberton, MN}

Total soil $\mathrm{C}$ to the 20 -cm depth was not significantly different among fertilizer treatment levels. Active fraction components were similar across treatments, although there was a weak trend toward increased soil $\mathrm{C}$ pools with increased $\mathrm{N}$ fertilizer rates. There was significantly less POM in the lowest $\mathrm{N}$ application treatment and, unexpectedly, less $\mathrm{CHCl}_{3}$ labile $\mathrm{C}$ in the highest $\mathbf{N}$ treatment.

\section{Lexington, $\mathrm{KY}$}

Soil $\mathrm{C}$ was greater with increasing fertilizer additions in the conventionally tilled (CT) treatment, but was not different among fertility levels in the 
Table 12-2. Amounts of total $\mathrm{C}$ and active fraction $\mathrm{C}$ pools for selected Corn Belt sites.

\begin{tabular}{|c|c|c|c|c|c|c|c|c|}
\hline \multirow{2}{*}{$\begin{array}{l}\text { Site } \\
\text { treatment }\end{array}$} & \multirow[b]{2}{*}{ Total } & \multirow[b]{2}{*}{ POM† } & \multirow{2}{*}{$\begin{array}{l}\mathrm{CHCl}_{3} \\
\text { labile }\end{array}$} & \multirow[b]{2}{*}{ Mineralized $\ddagger$} & \multicolumn{3}{|c|}{ Particle size } & \multirow{2}{*}{$\begin{array}{c}\text { Bulk } \\
\text { density }\end{array}$} \\
\hline & & & & & Sand & Silt & Clay & \\
\hline & - & \multicolumn{3}{|c|}{$\mathrm{Mg} \mathrm{C} \mathrm{ha}^{-1}$ (to $20 \mathrm{~cm}$ ) } & & $\mathrm{g} \mathrm{g}^{-1}$ & & $\mathrm{Mg} \mathrm{m}^{-3}$ \\
\hline \multicolumn{9}{|c|}{ Lamberton, MN } \\
\hline CT-16\$ & $56 a^{*}$ & $3.0 \mathrm{a}$ & $0.34 a$ & $1.4 \mathrm{a}$ & $0.37 a$ & $0.33 a$ & $0.30 \mathrm{a}$ & $1.38 \mathrm{a}$ \\
\hline CT-106 & $61 a$ & $4.6 \mathrm{~b}$ & $0.41 b$ & $1.5 \mathrm{a}$ & $0.33 a$ & $0.34 a$ & $0.33 a$ & $1.35 a$ \\
\hline CT-195 & $62 a$ & $4.4 \mathrm{~b}$ & $0.27 a$ & $1.6 \mathrm{a}$ & $0.36 a$ & $0.34 a$ & $0.30 \mathrm{a}$ & $1.33 \mathrm{a}$ \\
\hline \multicolumn{9}{|c|}{ Lexington, $\mathrm{KY}$} \\
\hline CT-0 & $30 a$ & $3.6 \mathrm{a}$ & $0.29 a$ & $2.1 \mathrm{a}$ & $0.07 a$ & $0.63 a$ & $0.30 \mathrm{~b}$ & $1.27 \mathrm{a}$ \\
\hline CT-84 & $34 \mathrm{ab}$ & $4.7 a$ & $0.30 \mathrm{a}$ & 2.5ab & $0.07 a$ & $0.63 a$ & $0.30 \mathrm{~b}$ & $1.27 \mathrm{a}$ \\
\hline CT-164 & $40 \mathrm{~b}$ & $6.3 \mathrm{~b}$ & $0.23 a$ & $3.0 \mathrm{c}$ & $0.08 \mathrm{a}$ & $0.64 \mathrm{ab}$ & $0.29 \mathrm{~b}$ & $1.29 \mathrm{a}$ \\
\hline NT-0 & $37 \mathrm{~b}$ & $4.3 a$ & $0.42 b$ & $2.4 \mathrm{ab}$ & $0.07 \mathrm{a}$ & $0.64 a b$ & $0.29 \mathrm{~b}$ & $1.32 \mathrm{a}$ \\
\hline NT-84 & $40 \mathrm{~b}$ & $6.3 \mathrm{~b}$ & $0.23 a$ & $2.6 \mathrm{~b}$ & $0.08 \mathrm{a}$ & $0.66 \mathrm{~b}$ & $0.27 \mathrm{a}$ & $1.28 \mathrm{a}$ \\
\hline NT-164 & $37 \mathrm{~b}$ & $7.0 \mathrm{~b}$ & $0.30 a$ & $3.3 \mathrm{c}$ & $0.08 a$ & $0.64 a b$ & $0.28 \mathrm{ab}$ & $1.21 \mathrm{a}$ \\
\hline \multicolumn{9}{|c|}{ W. Lafayette, IN } \\
\hline CT-CS & $60 a$ & $5.3 \mathrm{a}$ & $0.28 a$ & $2.1 \mathrm{a}$ & $0.15 a$ & $0.51 \mathrm{a}$ & $0.34 a$ & $1.20 \mathrm{a}$ \\
\hline CT-CC & $77 \mathrm{a}$ & $6.4 \mathrm{a}$ & $0.35 a$ & $2.7 b c$ & $0.14 a$ & $0.49 a$ & $0.37 \mathrm{a}$ & $1.25 \mathrm{ab}$ \\
\hline NT-CS & $73 a$ & $7.6 \mathrm{a}$ & $0.26 a$ & $2.4 \mathrm{ab}$ & $0.15 a$ & $0.49 a$ & $0.34 a$ & $1.23 \mathrm{ab}$ \\
\hline NT-CC & $65 a$ & $10.1 \mathrm{a}$ & $0.32 a$ & $3.0 \mathrm{c}$ & $0.15 a$ & $0.53 a$ & $0.32 \mathrm{a}$ & $1.31 b$ \\
\hline \multicolumn{9}{|c|}{ Conventional tillage-continuous corn across sites } \\
\hline MN & $61 b$ & $4.6 a$ & $0.41 \mathrm{a}$ & $1.5 \mathrm{a}$ & $0.33 c$ & $0.34 a$ & $0.33 a$ & $1.35 \mathrm{a}$ \\
\hline KY & $34 a$ & $4.7 a$ & $0.30 a$ & $2.5 b$ & $0.07 a$ & $0.63 c$ & $0.30 a$ & $1.27 \mathrm{a}$ \\
\hline IN & $77 \mathrm{c}$ & $6.4 \mathrm{~b}$ & $0.35 a$ & $2.7 \mathrm{~b}$ & $0.14 b$ & $0.49 b$ & $0.37 \mathrm{~b}$ & $1.25 \mathrm{a}$ \\
\hline
\end{tabular}

* For comparisons across tillage or fertility treatments within each site, values followed by the same letter are not different at $P=0.05$ using LSD mean separation tests.

$\dagger \mathrm{POM}=$ particulate organic matter.

$¥$ Cumulative respiration at $91 \mathrm{~d}$.

$\S \mathrm{CT}=$ conventional tillage; $\mathrm{NT}=$ no-tillage $\mathrm{CC}=$ continuous corn rotation; $\mathrm{CS}=$ cornsoybean rotation (all crops at Lamberton and Lexington are continuous corn); numbers following treatment indicate fertilizer additions in $\mathrm{kg} \mathrm{N} \mathrm{ha}^{-1} \mathrm{yr}^{1}$.

no-till (NT) treatment. No-till organic matter levels were higher than CT at the lowest fertility level, but not at the higher two levels. These trends were essentially repeated for the POM fraction. Chloroform extractable $\mathrm{C}$ was not different among treatments, except at the lowest fertilizer level where NT was greater than CT. Mineralized C was greater at the highest compared with lowest fertility levels within each cultivation treatment.

\section{West Lafayette, IN}

Within-treatment variability was high for this site, perhaps due to the irregular occurrence of two different soil series (see Table 12-1) across the plots. Total $\mathrm{C}$ and active fraction components were not significantly differnet for tillage method or crop rotation, except for mineralized C. Mineralized $\mathrm{C}$ was significantly higher in continuous corn (Zea mays L.) than in corn-soybean [Glycine max (L.) Merr.] rotations and there was a trend for it to increase under no-till compared with conventional tillage. 


\section{Cross-Site Comparison of Continuous Corn with Conventional Tillage}

Cross-site comparisons were made for the common treatment of continuous corn, moldboard plow tillage, and $\mathrm{N}$ fertilizer rates of $\sim 80$ to 100 $\mathrm{kg} \mathrm{ha}^{-1} \mathrm{yr}^{-1}$. The two prairie-derived soils (Lamberton and W. Lafayette) had more total soil $\mathrm{C}$ than the forest-derived soil (Lexington). Soil textures differed primarily in sand and silt content, with the Kentucky and Indiana sites having the finest textures. Interestingly, the Lamberton site showed a much lower activity for mineralized $\mathrm{C}$ and the relative size of all measured active $\mathrm{C}$ fractions compared to total carbon was lower than for the other two sites.

\section{Great Plains Sites (Table 12-3)}

Sidney, NE

Bulk density was greater in the bare fallow and NT than in stubble mulch and native grassland treatments. The native grassland and NT treatments had greater amounts of total soil $\mathrm{C}$ than bare fallow and stubble mulch treatments. There was more POM-C in the native grassland treatment than the other treatments and NT had more POM than stubble mulch or bare fallow. Chloroform labile $\mathrm{C}$ was greater in the NT treatment than bare fallow. Mineralized $\mathrm{C}$ increased with decreasing soil disturbance due to tillage.

\section{Akron, CO}

Sand content of the soil was greater in the native grassland than stubble mulch or NT treatments, whereas the bulk density was lowest in the native grassland treatment. The stubble mulch and NT treatments were not different from each other and were less than the native grassland treatment for total $\mathrm{C}$ and all active fraction soil $\mathrm{C}$ pools.

\section{Abandoned and Native Grassland Pawnee Grassland Treatments}

No differences were observed between abandoned and native treatments for Sites 1 and 2, except at Site 1 where mineralized $C$ in the abandoned treatment was greater than that in the native grassland treatment. At Site 3, the total soil $\mathrm{C}$ and all active fractions were greater in the native than the abandoned treatments.

\section{Comparison of Native Grassland Treatments across Sites}

Sand related directly to the bulk density of the undisturbed soils. Patterns within the three Pawnee Grassland sites showed that increasing clay content positively correlated with all measured soil C pools. The Sidney site had the most precipitation (data not shown) and the highest levels of total $\mathrm{C}$ and POM-C. Pawnee Grassland Site 3 had the highest clay content and microbial biomass levels. 
Table 12-3. Amounts of total $\mathrm{C}$ and active fraction $\mathrm{C}$ pools for selected Great Plains sites.

\begin{tabular}{|c|c|c|c|c|c|c|c|c|}
\hline \multirow[b]{2}{*}{ Site treatment } & \multirow[b]{2}{*}{ Total } & \multirow[b]{2}{*}{ POM† } & \multirow{2}{*}{$\begin{array}{l}\mathrm{CHCl}_{3} \\
\text { labile }\end{array}$} & \multirow[b]{2}{*}{ Mineralized $\ddagger$} & \multicolumn{3}{|c|}{ Particle size } & \multirow{2}{*}{$\begin{array}{c}\text { Bulk } \\
\text { density }\end{array}$} \\
\hline & & & & & Sand & Silt & Clay & \\
\hline & - & \multicolumn{3}{|c|}{$\mathrm{Mg} \mathrm{C} \mathrm{ha}^{-1}$ (to $20 \mathrm{~cm}$ ) - } & & $g g^{-1}$ & & $\mathrm{Mg} \mathrm{m}^{-3}$ \\
\hline \multicolumn{9}{|c|}{ Sidney, NE } \\
\hline BF§ & $28 \mathrm{a}^{*}$ & $3.5 \mathrm{a}$ & $3.37 \mathrm{ab}$ & $1.4 \mathrm{a}$ & $0.41 \mathrm{~b}$ & $0.32 a$ & $0.26 a$ & $1.13 a$ \\
\hline SM & $28 a$ & $4.2 \mathrm{a}$ & $0.33 a$ & $1.5 \mathrm{a}$ & $0.35 a$ & $0.37 a$ & $0.28 \mathrm{a}$ & $0.92 a$ \\
\hline NT & $36 \mathrm{~b}$ & $5.1 b$ & $0.58 \mathrm{~b}$ & $2.2 b$ & $0.33 a$ & $0.38 \mathrm{a}$ & $0.29 a$ & $1.10 \mathrm{~b}$ \\
\hline NG & $38 \mathrm{~b}$ & $11.1 \mathrm{c}$ & 5.52ab & $2.7 \mathrm{c}$ & $0.35 a$ & $0.42 a$ & $0.23 a$ & $0.94 a$ \\
\hline \multicolumn{9}{|c|}{ Akron, CO } \\
\hline SM & $17 \mathbf{a}$ & $2.5 \mathrm{a}$ & $0.32 \mathrm{a}$ & $1.5 \mathrm{a}$ & $0.34 a$ & $0.42 a$ & $0.27 \mathrm{~b}$ & $1.16 \mathrm{ab}$ \\
\hline NT & $15 a$ & $2.5 \mathrm{a}$ & $0.33 a$ & $1.5 \mathrm{a}$ & $0.36 a$ & $0.39 a$ & $0.25 \mathrm{ab}$ & $1.23 \mathrm{~b}$ \\
\hline NG & $25 b$ & $8.1 b$ & $0.60 \mathrm{~b}$ & $2.3 b$ & $0.44 b$ & $0.35 a$ & $0.20 \mathrm{a}$ & $1.01 \mathrm{a}$ \\
\hline \multicolumn{9}{|c|}{ Successional grasslands } \\
\hline \multicolumn{9}{|c|}{ Pawnee Grassland 1} \\
\hline $\mathrm{AB}$ & $18 \mathrm{NS}$ & $3.4 \mathrm{NS}$ & $0.64 \mathrm{NS}$ & $2.4^{*}$ & $0.71 \mathrm{NS}$ & $0.13 \mathrm{NS}$ & $0.17 \mathrm{NS}$ & $1.33 \mathrm{NS}$ \\
\hline NG & 20 & 3.6 & 0.65 & 1. & 0.72 & 0.13 & 0.15 & 1.3 \\
\hline \multicolumn{9}{|c|}{ Pawnee Grassland 2} \\
\hline AB & $22 \mathrm{NS}$ & $5.4 \mathrm{NS}$ & $1.08 \mathrm{NS}$ & $2.7 \mathrm{NS}$ & $0.60 \mathrm{NS}$ & $0.25 \mathrm{NS}$ & $0.15 \mathrm{NS}$ & $1.34 \mathrm{NS}$ \\
\hline NG & 24 & 6.2 & 0.87 & 2.7 & 0.52 & 0.30 & 0.19 & 1.23 \\
\hline \multicolumn{9}{|c|}{ Pawnee Grassland 3} \\
\hline $\mathrm{AB}$ & $24^{*}$ & $5.3^{*}$ & $0.94^{*}$ & $2.6^{*}$ & $0.53 \mathrm{NS}$ & $0.15 \mathrm{NS}$ & $0.32 \mathrm{NS}$ & $1.29 \mathrm{NS}$ \\
\hline NG & 30 & 8.1 & 1.11 & 3.3 & 0.54 & 0.17 & 0.30 & 1.24 \\
\hline \multicolumn{9}{|c|}{ Native grassland comparison } \\
\hline Sidney & $38 \mathrm{c}$ & $11.1 \mathrm{c}$ & $0.52 a$ & $2.7 \mathrm{c}$ & $0.35 a$ & $0.42 \mathrm{c}$ & $0.23 \mathrm{ab}$ & $0.94 a$ \\
\hline Akron & $25 a b$ & $8.1 \mathrm{~b}$ & & & $0.44 a b$ & $0.35 c$ & & $1.01 \mathrm{a}$ \\
\hline $\begin{array}{l}\text { Pawnee } \\
\text { Grassland } 1\end{array}$ & $20 a$ & $3.6 \mathrm{a}$ & $0.65 a$ & $1.5 \mathrm{a}$ & $0.72 \mathrm{c}$ & $0.12 \mathrm{a}$ & $0.15 a$ & $1.36 \mathrm{~b}$ \\
\hline $\begin{array}{l}\text { Pawnee } \\
\text { Grassland } 2\end{array}$ & $24 a$ & $6.2 \mathrm{~b}$ & $0.87 \mathrm{~b}$ & $2.7 \mathrm{~cd}$ & $0.52 b$ & $0.30 \mathrm{bc}$ & $0.19 a$ & $1.23 \mathrm{~b}$ \\
\hline $\begin{array}{l}\text { Pawnee } \\
\text { Grassland } 3\end{array}$ & $30 \mathrm{~b}$ & $8.1 b$ & $1.11 \mathrm{c}$ & $3.3 \mathrm{~d}$ & $0.54 b$ & $0.17 \mathrm{ab}$ & $0.29 b$ & $1.24 \mathrm{~b}$ \\
\hline
\end{tabular}

* Significant at $p=0.05$. Values followed by the same letter are not different at $p=$ 0.05 using LSD mean separation tests; NS = not significant.

$\dagger \mathrm{POM}=$ particulate organic matter.

$\ddagger$ Cumulative respiration at $91 \mathrm{~d}$.

$\S \mathrm{BF}=$ bare fallow; $\mathrm{SM}=$ stubble mulch; $\mathrm{NT}=$ no-tillage; $\mathrm{NG}=$ native grassland; $\mathrm{AB}$ = abandoned.

\section{DISCUSSION}

The largest differences among treatments were observed between the native and cultivated systems. Relative differences across sites within native grasslands, for the Great Plains sites, and within conventional tillagecontinuous corn, for the Corn Belt sites, were greater than most differences observed within sites across management treatments. The more mesic Corn Belt sites had larger amounts of soil $C$ than the Great Plains sites due to the greater primary production, hence higher $\mathrm{C}$ inputs leading to higher total $\mathrm{C}$ levels. The Corn Belt soils developed under tallgrass prairie or decidu- 
ous forest (Lexington) and the Great Plains soils developed under short or midgrass prairie. Interestingly, the active fraction pools were similar between the two regions, suggesting that potentially a higher proportion of total soil $\mathrm{C}$ was biologically active in the Great Plains than Corn Belt region.

In many cases relative differences among treatments was greater for active fraction pools than total soil $\mathrm{C}$, but the number of treatments that were statistically different from each other within a site were no greater. This trend indicates that although the active fraction pools may be more sensitive to treatment influences, they are also more variable.

\section{Corn Belt}

Carbon mineralization and POM-C appear to be the most sensitive indicators of management effects on SOM within this region. The greater POM$\mathrm{C}$ and mineralized C levels for NT, in particular, suggests increased potential for $\mathrm{C}$ availability to soil heterotrophs. Average organic matter levels to a depth of $20 \mathrm{~cm}$ were generally greater with reduced tillage and increased $\mathrm{N}$ application, but to varying degrees at different sites. Crop rotation effects on soil $C$ pools, represented at the Indiana site, were clearly differentiated only for mineralized $C$, but variability in $C$ pools across field replicates was much higher at W. Lafayette than the other two sites.

Although having a total soil $\mathrm{C}$ level intermediate between the other two sites, Lamberton, $\mathrm{MN}$, exhibited lower $\mathrm{C}$ mineralization rates and smaller active $\mathrm{C}$ pools relative to total $\mathrm{C}$. The continuous corn-conventional tillage management practice with 80 to $100 \mathrm{~kg} \mathrm{~N}^{-1}$ added every year yielded similar results for POM and biomass pools, but $\mathrm{C}$ mineralization rates underscored the strong differences in the amount of labile $\mathrm{C}$ in the Lamberton soil compared with the other two sites. In contrast to the cross-site comparison within the Great Plains, texture was not closely associated with soil C content. Lexington had the highest silt plus clay content but the lowest soil $\mathrm{C}$, emphasizing the overwhelming influence of soil genesis on soil $\mathrm{C}$ levels.

\section{Great Plains}

Total soil C levels at the Sidney site were comparable in the native grassland and NT treatments, even $20 \mathrm{yr}$ after being plowed out of grass. Tilled soils (stubble mulch and bare fallow) showed large losses of C. At Akron, where treatments were established in previously cultivated soil, the trend was different; the stubble mulch and NT treatments were similar in all respects and much lower than the native site. Precipitation at Akron is less than at Sidney, but Akron soils have been cultivated longer. Akron treatments (except native grassland) were initiated in degraded soils ( $\sim 60 \mathrm{yr}$ of cultivation), whereas Sidney treatments were begun on previously uncultivated grassland soils. A number of factors vary simultaneously between the two sites, so it is not possible to unambiguously explain observed differences. Data from additional sites will be needed to determine how management affects soil organic matter levels across the central USA. 
Soils from the Pawnee Grassland abandoned from cultivation for approximately $50 \mathrm{yr}$ have nearly recovered their original total soil $\mathrm{C}$ levels. At Site 2, which had the sandiest soil, the mineralized $C$ in the abandoned treatment surpassed the native site. The native grassland treatment at Site 3 maintained higher levels of mineralized $\mathrm{C}$ compared with abandoned. This soil had the highest clay content.

Data presented in this article has demonstrated that management can control amounts of $\mathrm{C}$ in soils differentially under different soil-climatemanagement combinations. Further analysis of the wider range of network sites will assist understanding the extent to which increases in atmospheric $\mathrm{CO}_{2}$ can be ameliorated by increases in total soil $\mathrm{C}$ as a result of management. Although we accept the many roles that soil organic matter plays in determining the quality of soil, it also influences the quality of the global enviornment as a sink for atmospheric $\mathrm{CO}_{2}$.

\section{SUMMARY}

Soil organic matter is recognized as an important component of soil quality through its influence on soil physical properties and the cycling of nutrients. Interest in soil organic matter has expanded to include its role in the worldwide $C$ budget and climate change. The research described here was initiated to help assess the potential for $C$ sequestration in agricultural soils of the Great Plains and Corn Belt regions to ameliorate the buildup of atmospheric $\mathrm{CO}_{2}$. In addition, a better understanding of what factors govern soil organic matter pool sizes is relevant to the assessment of soil quality and its response to management.

For the Corn Belt sites, $\mathrm{C}$ mineralization and POM-C were the most sensitive indicators of management effects on soil organic matter. No-till generally showed increased amounts of POM and mineralized $\mathrm{C}$ in the top $20 \mathrm{~cm}$, suggesting increases in labile $C$ fractions compared with conventional tillage. Mean organic matter levels to a depth of $20 \mathrm{~cm}$ generally increased with reduced tillage and higher $\mathrm{N}$ application, but to varying degrees at different sites.

Within the Great Plains sites, tilled soils (stubble mulch and bare fallow) showed large losses of C. Where NT was initiated on previously uncultivated soils at Sidney, NE, total soil C levels were comparable to the native grassland, even after $20 \mathrm{yr}$. No-till on previously degraded soil ( $\sim 60 \mathrm{yr}$ of cultivation) at Akron had $C$ levels similar to stubble mulch and much lower than the native grassland. Carbon levels in two of three successional grassland sites had recovered to near those in the native systems after $50 \mathrm{yr}$. As with the Corn Belt sites, POM and mineralized $C$ values showed the greatest differences among tillage treatments.

\section{REFERENCES}

Anderson, J.P.E. 1982. Soil respiration. p. 831-871. In A.L. Page (ed.) Methods of soil analysis. Part 2. 2nd ed. Agron. Monogr. 9. ASA and SSSA, Madison, WI.

Arshad, M.A., and G.M. Coen. 1992. Characterization of soil quality: Physical and chemical criteria. Am. J. Altern. Agric. 7:25-32. 
Barnwell, T.O., R.B. Jackson, E.T. Elliott, I.C. Burke, C.V. Cole, K. Paustian, E.A. Paul, A.S. Donigian, A.S. Patwardhan, A. Rowell, and K. Weinrich. 1992. An approach to assessment of management impacts on agricultural soil carbon. Water Air Soil Pollut. 64:423-435.

Blevins, R.L., G.W. Thomas, M.S. Smith, W.W. Frye, and P.L. Cornelius. 1983. Changes in soil properties after 10 years continuous non-tilled and conventionally tilled corn. Soil Tillage Res. 3:135-146.

Cambardella, C.A., and E.T. Elliott. 1992. Particulate soil organic-matter changes across a grassland cultivation sequence. Soil Soc. Sci. Am. J. 56:777-783.

Campbell, C.A. 1978. Soil organic carbon, nitrogen and fertility. p. 173-271. In M. Schnitzer and S.U. Khan (ed.) Soil organic matter. Dev. in Soil Sci. 8. Elsevier, New York.

Elliott, E.T., and C.V. Cole. 1989. A perspective on agroecosystem science. Ecology 70:1597-1602.

Elliott, E.T., C.V. Cole, and C.A. Cambardella. 1993. Modification of ecosystem processes by management and the mediation of soil organic matter dynamics. p. 257-268. In K. Mulongoy and R. Mercx (ed.) The dynamics of soil organic matter in relation to the sustainability of tropical agriculture. John Wiley \& Sons, New York.

Fenster, C.R., and G.A. Peterson. 1979. Effects of no-tillage fallow compared to conventional tillage in a wheat fallow system. Nebraska Agric. Exp. Stn. Res. Bull. 289.

Granatstein, D., and D.F. Bezdicek. 1992. The need for a soil quality index: Local and regional perspectives. Am. J. Altern. Agric. 7:12-16.

Haas, H.J., and C.E. Evans. 1957. Nitrogen and carbon changes in Great Plains soils as influenced by cropping and soil treatments. USDA Tech. Bull. 1164. U.S. Gov. Print. Office, Washington, DC.

Jenkinson, D.S., P.B.S. Hart, J.H. Rayner, and L.C. Parry. 1987. Modelling the turnover of organic matter in long-term experiments at Rothamsted. In J.H. Cooley (ed.) Soil organic matter dynamics and soil productivity. INTECOL Bull. 15. Int. Assoc. for Ecol., Athens, GA.

Jenny, A. 1941. Factors of soil formation. McGraw-Hill, New York.

Nelson, W.W., and J.M. MacGregor. 1973. Twelve years of continuous corn fertilization with ammonium nitrate or urea nitrogen. Soil Sci. Soc. Am. J. 37:583-586.

Parton, W.J., D.S. Schimel, C.V. Cole, and D.S. Ojima. 1987. Analysis of factors controlling soil organic matter levels in Great Plains grasslands. Soil Sci. Soc. Am. J. 51:1173-1179.

Paustian, K., W.J. Parton, and J. Persson. 1992. Modeling soil organic matter in organicamended and nitrogen-fertilized long-term plots. Soil Sci. Soc. Am. J. 56:476-488.

Post, W.M., T.H. Peng, W.R. Emanuel, A.W. King, V.H. Dale, and D.L. DeAngelis. 1990. The global carbon cycle. Am. Sci. 78:310-326.

Schreiber, M.M., T.S. Abney, and J.E. Foster. 1987. Integrated pest management systems: A research approach. Res. Bull. 985. AES, Pursue Univ., W. Lafayette, IN.

Smika, D.E. 1990. Fallow management practices for wheat production in the Central Great Plains. Agron. J. 82:319-323.

Snyder, J.D., and J.A. Trofymow. 1984. A rapid accurate wet oxidation diffusion procedure for determining organic and inorganic carbon in plant and soil samples. Commun. Soil Sci. Plant Anal. 15:587-597.

Tate, K.R., D.J. Ross, and C.W. Feltham. 1988. A direct extraction method to estimate soil microbial C: Effects of experimental variables and some calibration procedures. Soil Biol. Biochem. 20:329-335.

Vance, E.D., P.C. Brookes, and D.S. Jenkinson. 1987. An extraction method for measuring soil microbial biomass C. Soil Biol. Biochem. 19:703-707.

Wilson, A.T. 1978. The explosion of pioneer agriculture: Contribution to the global $\mathrm{CO}_{2}$ increase. Nature (London) 273:40-42. 